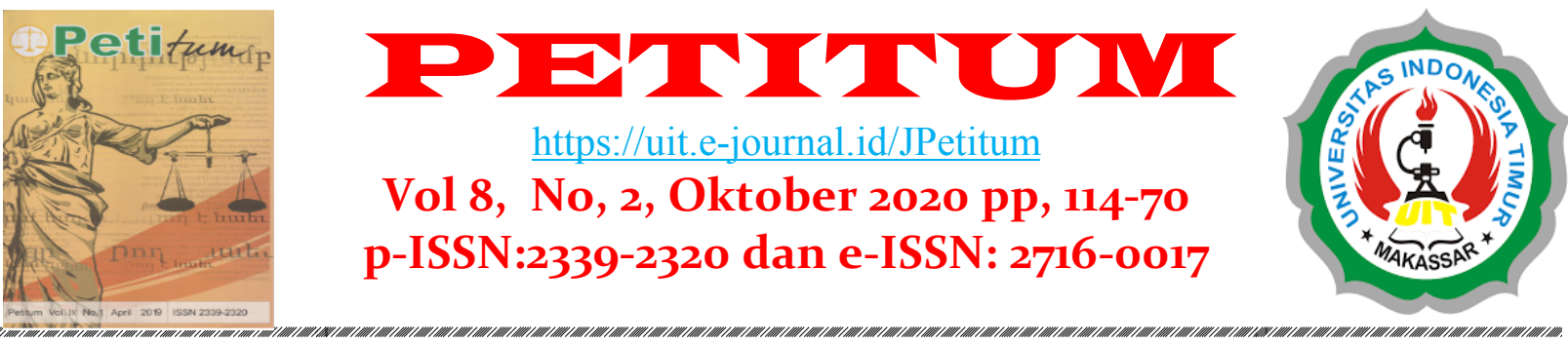

\title{
Tantangan Pemulihan Lingkungan di Masa Pandemi Covid- 19: Antara Idealita dan Realita
}

\section{Zulfadhly Sanusi ${ }^{1}$}

${ }^{1}$ Magister Hukum, Universitas Indonesia, Email: zulfadhlysanusi@gmail.com

\section{Keywords:}

Responsibility,

Environmental

Recovery, Covid-19,

Corporation, State

\section{Kata Kunci:}

Tanggungjawab,

Pemulihan

Lingkungan, Covid-19,

Korporasi, Negara
ABSTRACT: The research aims at examining the role of the State in the social and economic sustainability of natural resources around mining and the role of the community in enforcing environmental laws. This type of research uses normative legal research. The results of the study suggest that the responsibility of the State in restoring the mining environment must be carried out in the entire process starting from the stages of fulfilling permits, planning, implementing and controlling because the responsibility of business entities has not yet been regulated by the possibility of contaminating exmining areas after handover to the government. Post-mining environmental restoration activities only involve the authorities of the government and mining business actors without involving the community as an important element as well as parties directly related to the physical, economic and social environment of the mining environment.

ABSTRAK: Penelitian bertujuan tentang meninjau peran Negara atas keberlanjutan sumber daya alam di sekitar pertambangan secara sosial dan ekonomi dan peran serta masyarakat dalam penegakan hukum lingkungannya. Jenis penelitian ini menggunakan penelitian hukum normatif. Hasil penelitian mengemukakan bahwa tanggungjawab Negara dalam pemulihan lingkungan pertambangan harus dilakukan pada seluruh proses mulai dari tahapan pemenuhan perizinan, perencanaan, pelaksanaan dan pengawasan karena belum diaturnya tanggungjawab oleh badan usaha terhadap kemungkinan pencemaran bekas lahan tambang setelah penyerahan kepada pemerintah. Kegiatan pemulihan lingkungan pada pascatambang hanya melibatkan kewenangan pemerintah dan pelaku usaha pertambangan tanpa melibatkan masyarakat sebagai unsur penting dan juga pihak yang terkait langsung dengan keberadaan lingkungan fisik, ekonomi maupun sosial lingkungan pertambangan. 


\section{PENDAHULAN}

Pengaturan permasalahan lingkungan hidup di Indonesia mengalami beberapa lompatan besar sejak diundangkannya Undang-Undang Nomor 4 Tahun 1982 tentang Ketentuan-ketentuan Pokok Pengelolaan Lingkungan Hidup, kemudian digantikan dengan Undang-Undang Nomor 23 Tahun 1997 tentang Pengelolaan Lingkungan Hidup, dan terakhir digantikan dengan diberlakukannya UndangUndang Nomor 32 Tahun 2009 tentang Perlindungan dan Pengelolaan Lingkungan Hidup.

Salah satu yang menjadi perhatian dalam ketiga undang-undang ini adalah makin kuatnya peran negara dalam rangka menyediakan lingkungan hidup yang baik dan sehat sebagai sarana rakyat Indonesia berkehidupan. Undang-Undang Dasar Negara Republik Indonesia Tahun 1945 telah menyatakan bahwa lingkungan hidup yang baik dan sehat merupakan hak asasi dan hak konstitusional bagi setiap warga negara Indonesia.

Karena itu, negara, pemerintah, dan seluruh pemangku kepentingan berkewajiban untuk melakukan perlindungan dan pengelolaan lingkungan hidup dalam pelaksanaan pembangunan berkelanjutan agar lingkungan hidup Indonesia dapat tetap menjadi sumber dan penunjang hidup bagi rakyat Indonesia serta makhluk hidup lain.

Pemanfaatan sumber daya alam oleh manusia haruslah diperhatikan soal tujuan dan dampak yang dapat ditimbulkan akibat pemakaian oleh manusia. Masyarakat dan pemerintah harus saling memnjaga dan mendukung dalam menjaga lingkungan hidup, dikarenakan bila terjadinya masalah dalam lingkungan hidup, hal tersebut dapat menentukan keberlangsungan hidup dari manusia dan mahluk hidup lainnya yang juga dapat berpengaruh terhadap sebuah negara. Namun keadaan tersebut sebaliknya, manusia dan mahluk hidup lainnya dapat menjaga keberlangsungan lingkungan hidup dengan cara menjaganya dan melakukan pemanfaatan secara berkala dan teratur serta melakukan perbaikan ulang terhadap lingkungan agar tidak terjadi kerusakan akibat dari pemakaian manusia (Suprijandi, 2019).

Banyaknya kejadian alam yang terjadi belakangan ini, harusnya menjadi acuan bagi pemerintah untuk lebih memperhatikan permasalahan lingkungannya. Efek sosialnya yang lebih dahsyat dari kerusakan lingkungan hidup adalah munculnya konflik-konflik horisontal, pengungsi pembangunan, epidemi sosial, gejala ecocide, konflik sosial, hancurnya sistem lokal, perubahan biologis, penurunan kualitas hidup, munculnya penyakit-penyakit sosial, seperti prostitusi dan kriminalitas, kekerasan dalam rumah tangga, kemiskinan struktural serta pelanggaran hak asasi manusia. Pengembangan di sektor Tambang diperlukan demi pendapatan nasional dan daerah karena bertujuan untuk kemajuan pembangunan secara nasioanal (Soemarwoto, 2001).

Dengan diundangkannya Undang-undang No.32 Tahun 2009, dapat dikatakan bahwa: undang-undang telah menempatkan lingkungan hidup yang baik dan sehat sebagai jaminan hak asasi warga Negara yang diatur dalam Pasal $28 \mathrm{H}$ UndangUndang Dasar Negara Republik Indonesia Tahun 1945 tentang mendapatkan tempat tinggal dan lingkungan hidup yang baik dan sehat tidak terpenuhi diakibatkan kurangnya penegakan dalam pemulihan lingkungan hidup bekas tambang 
khususnya pada kondisi pandemic saat ini. Seiring dengan munculnya bencana pandemic Covid-19, yang menyebabkan lemahnya dan berkurangnya kegiatan investasi sehingga terjadi penurunan nilai saham dan bisnis dari perusahaanperusahaan tambang membuat mereka banyak melakukan pemangkasanan budget terutama soal urusan pemulihan lingkungan, bahkan sampai ada perusahaan yang gulung tikar atau pailit sehingga tidak mampu melakukan pemulihan lingkungan bekas tambang (Arkadia Digital Media, 2020). Apalagi saat ini belum ada lahir peraturan khusus terkait pemulihan lingkungan pada masa Covid-19.

Cara pandang adanya kesadaran bersama terhadap lingkungan yang semakin menurun kualitasnya, jadi perlu dilakukan komitmen bersama seluruh pemangku terhadap lingkungan hidup. Otonomi daerah yang juga mempengaruhi dalam penyelenggaran pemerintah daerah, karena itu upaya perlindungan dan pengelolaan lingkungan hidup harus ditekankan di daerah.Penanggulangan pencemaran daerah bekas tambang dapat realisasikan apabila adanya kesadaran antara pemerintah dan masyarakat daerah pertambangan tersebut. Dalam UndangUndang Nomor 4 Tahun 2009 tentang Pertambangan Mineral dan Batu Bara disebutkan dalam Pasal 3 sebagai berikut:

"Meningkatkan pendapatan masyarakat lokal, daerah, dan negara, serta menciptakan lapangan kerja untuk sebesarbesar kesejahteraan rakyat."

Dengan demikian menjadi tujuan dari kegiatan pertambangan adalah untuk kesejahteraan rakyat, maka dari itu setiap kegiatan pertambangan harus berdasarkan aturan yang berlaku sehingga benar-benar terwujudnya kesetaraan antara masyarakat dan Negara sesuai dengan aturan dalam Pasal 33 UUD NRI Tahun 1945 (Supriadi, 2008)

Dalam konteks pengelolaan lingkungan hidup berdasarkanUndang-undang Nomor 32 Tahun 2009 tentang Perlindungan dan Pengelolaan Lingkungan Hidup slenjutnya disebut UUPPLH, penegakan hukum lingkungan administratif dapat dilakukan melalui dua cara, yaitu secara preventif dan represif. Penegakan hukum lingkungan administratif yang bersifat preventif adalah dilakukan melalui pengawasan, sedangkan penegakan hukum yang represif dilakukan melalui penerapan sanksi administratif. Pengawasan dan penerapan sanksi administratif tersebut adalah bertujuan untuk mencapai ketaatan masyarakat terhadap norma hukum lingkungan administratif. Konsep kebijakan pengawasan pengelolaan lingkungan dalam konteks UUPPLH perlu diatur secara komprehensif yang meliputi pengawasan sendiri (self monitoring), self recording dan self reporting dengan melaporkan hasilnya ke instansi terkait, dan bersifat terbuka bagi masyarakat; pengawasan utama oleh inspektur dari instansi pemberi izin; pengawasan kedua dari instansi propinsi atau pemerintah (pusat) apabila instansi pertama gagal menjalankan fungsi pengawasannya. Pengawasan lainnya adalah pengawasan eksternal atau pengawasan publik(Mukhlish, 2010).

Mewujudkan pengelolaan lingkungan yang berbasis pada pembangunan berkelanjutan dibutuhkan konsep pengawasan publik terbuka dan seluas mungkin, terutama memberlakukan mekanisme keberatan secara administratif apabila prosedur perizinan dan masukan masyarakat diabaikan oleh instansi penerbit izin. Tentu saja untuk mengefektifkan pengawasan diperlukan strategi penghukuman yang tepat (sanctioning strategy) dari mulai pemberlakuan sanksi administratif yang 
ringan (peringatan satu, dua, dan tiga) sampai dengan pencabutan izin. Sanctioning strategy ini diperlukan untuk menghindari pemberian sanksi yang didasarkan pada kesewenang-wenangan. (Louglin, 1976).

Pengawasan pengelolaan lingkungan yang memadukan sistem "terpadu" dalam perspektif perizinan lingkungan hanya mengkonstatir perlunya "keterpaduan kebijaksanaan", sehingga tidak mencerminkan konsep dasar pengawasan pengelolaan lingkungan secara terpadu yang mempersyaratkan adanya "penyatuan" pengaturan (hukum) dan struktur administrasi (kewenangan maupun kelembagaan). Apabila diselami, dalam UUPPLH memang banyak ditemukan peristilahan "terpadu" yang terdapat perbedaan yang tidak relevan dengan teori pengawasan pengelolaan lingkungan secara terpadu. Sementara dalam kerangka fundamental pengawasan pengelolaan lingkungan secara terpadu dalam konteks pembangunan berkelanjutan bermaksud untuk mengkonstruksi adanya keterpaduan antara "policies" dan "institutions". Pengelolaan lingkungan hidup yang sektoral dapat memperlemah sustainable development. Hal ini bertentangan dengan pemikiran dari A.J Hoekema yang berpandangan bahwa pengawasan lingkungan secara terpadu adalah merefleksikan tindakan pemerintah yang baik, efektif Konsep Hukum Administrasi Lingkungan Dalam Mewujudkan Pembangunan Berkelanjutan dan absah(Mukhlish, 2010, p. 83).

Sebagaimana dalam UUPPLH tidak hanya Pemerintah Pusat dan Pemerintah daerah yang memiliki fungsi pengawasan, melainkan masyarakat juga memiliki hak dan kesempatan yang sama dalam berperan aktif untuk melakukan pengawasan dalam konteks perlindungan dan pengelolaan lingkungan hidup. Adapun peran pengawasan yang dapat dilakukan masyarakat dapat berupa :

a. Pengawasan sosial;

b. Pemberian saran, pendapat, usul, keberatan, pengaduan; dan/atau

c. Penyampaian informasi dan/atau laporan.

Dalam hal pengawasan yang di lakukan oleh Pemerintah baik itu Pusat maupun daerah wajib melakukan pengawasan terhadap ketaatan penanggung jawab usaha dan/atau kegiatan atas segala pengaturan yang telah diatur dalam peraturan perundang-undangan. Dalam menjalankan fungsi pengawasan baik pusat maupun daerah dapat mendelegasi kewenangannya kepada pejabat atau instansi yang bertanggung jawab dalam bidang perlindungan dan pengelolaan lingkungan hidup. Apabila dalam pengawasan ditemukan pelanggaran terhadap izin lingkungan maka Pemerintah baik pusat maupun daerah dapat memberikan sanksi administratif kepada pelaku usaha dan/atau kegiatan.

Terdapat pula sanksi terhadap pejabat yang berwenang apabila melakukan dengan sengaja tidak menjalankan fungsi pengawasan terhadap ketaatan penanggung jawab usaha dan/atau kegiatan yang mengakibatkan pencemaran dan/atau kerusakan lingkungan yang mengakibatkan hilangnya nyawa manusia sesuai pada Pasal 112 UUPPLH.

Berdasarkan latar belakang diatas maka dari itu penulis merumuskan masalah : Bagaimanakah penegakan hukum terhadap pemulihan lingkungan oleh korporasi dalam kegiatan pertambangan selama masa pandemic covid-19 ? bagaimanakah 
implikasi dari kegiatan investasi pertambangan terhadap kelestarian dan fungsi lingkungan yang berkelanjutan?

\section{METODE PENELITIAN}

Jenis penelitian yang digunakan dalam tulisan ini adalah penelitian hukum normatif dengan melalui metode pendekatan perundang-undangan (Statue Approach) dan pendekatan konseptual (Analytical and Conceptual Approach). Penelitian hukum normatif mengkaji dengan menitik beratkan pada penafsiran hukum dan konstruksi hukum untuk memperoleh aturan-aturan serta penerapan hukum yang melandasi pada tanggungjawab pemulihan lingkungan pada investasi pertambangan.

Penelitian ini juga melibatkan dimensi empiris secara proporsional atau yang dikenal sebagai socio-legal. Tujuannya agar dapat memberikan penjelasan tentang gejala hukum yang diinterpretasi secara factual, dimana factor sosial dapat dijelaskan dengan bantuan hukum, demikian pula kaidah-kaidah hukum dapat dijelaskan dengan bantuan fakta-fakta sosial (Bruggink, 1999).

Jenis dan sumber bahan hukum diperoleh dari penelitian kepustakaan. Bahan hukum primer adalah UUD 1945, peraturan perundang-undangan : UU No. 32 Tahun 2009 tentang Perlindungan Pengelolaan Lingkungan Hidup, UU No. 40 Tahun 2007 tentang Perseroan terbatas, dan UU No. 4 Tahun 2009 tentang Pertambangan Mineral dan Batubara serta konvensi Internasional tentang lingkungan hidup. Bahan hukum sekunder berupa bahan-bahan hukum yang dapat memberikan kejelasan terhadap bahan hukum primer seperti literature, hasil-hasil, makalah-makalah dalam seminar, artikel-artikel yang berkaitan dengan pengelolaan lingkungan hidup, pertambangan dan investasi. Bahan hukum tersier berupa bahanbahan hukum yang dapat memberikan petunjuk dan kejelasan pada bahan hukum primer maupun bahan hukum sekunder seperti kamus, ensiklopedia dan sebagainya.

Teknik pengumpulan bahan hukum yang digunakan adalah dengan melakukan penelitian dokumen dan pengamatan yaitu meneliti dan mengamati secara langsung dokumen-dokumen yang berkaitan dengan topik yang diteliti.

Analisis bahan hukum dengan menggunakan metode analisis juridis kualitatif dan hasil analisis disajikan dalam metode deskriptif analitis. Pengolahan dan penganalisaan data yang dilakukan dengan menggunakan metode pendekatan kulitatif menekankan pada segi pengamatan langsung secara partisipatif dari penelitian. Dengan demikian dapat diungkapkan fenomena-fenomena yang terjadi serta hal-hal yang melatar belakanginya yang pada akhirnya akan menghasilkan gambaran yang jelas, terarah dan menyeluruh dari masalah yang menjadi objek penelitian.

\section{HASIL DAN PEMBAHASAN}

\section{A. Penegakan Hukum Lingkungan yang Diberlakukan Negara Terhadap Korporasi dalam Kegiatan Investasi Tambang Selama Masa Pandemi Covid- 19}

Hukum pertambangan sebagai salah satu bidang ilmu hukum memiliki berbagai dimensi, salah satunya di bidang lingkungan karena objek dari aktivitas 
pertambangan adalah lingkungan. Dalam hal ini lingkungan yang dimaksud adalah baik biotik maupun abiotik. Hukum pertambangan menempatkan aspek lingkungan sebagai aspek penting karena adanya dinamika dan perubahan terhadap perubahan sifat dan fisik dari lingkungan tersebut sehingga diperlukan perlakuan khusus terhadap lingkungan sehingga diharapkan lingkungan yang dikelola akibat aktivitas pertambangan senantiasa memiliki fungsi dan daya lingkungan hidup yang terjaga atau malah dimungkinkan meningkat (Saleng, 2004).

Menurut Siti Sundari Rangkuti bahwa penegakan hukum terkait lingkungan berkaitan erat dengan kemampuan aparatur dan kepatuhan warga masyarakat terhadap peraturan yang berlaku, yang meliputi tiga bidang hukum, yaitu administratif, pidana dan perdata, hal ini senada dengan pengertian penegakan hukum lingkungan yang dikemukakan oleh Biezeveld sebagai berikut (Rangkuti, 2003):

Penegakan hukum lingkungan bisa didefinisikan sebagai penerapan hukum kekuatan pemerintah untuk memastikan kepatuhan dengan peraturan lingkungan dengan cara :

a. Pengawasan administrasi kepatuhan terhadap peraturan lingkungan(Inspeksi) (terutama preventif aktivitas);

b. Tindakan atau tindakan administratif dalam kasus ketidakpatuhan (korektif aktivitas)

c. Investigasi pidana dalam kasus yang diduga pelanggaran (aktivitas represif);

d. Cara pidana atau sanksi dalam kasus offeces (aktivitas represif);

e. Tindakan sipil (gugatan hukum) dalam kasus (mengancam) ketidakpatuhan (preventif atau aktivitas korektif)

I.S Susanto berpendapat bahwa terdapat minimal empat dimensi yang dapat mempengaruhi kualitas penegakan hukum lingkungan yaitu adanya Undangundang lingkungan secara nyata, pelanggar hukumnya sendiri, korban (masyarakat), dan aparat penegak hukum, dimana keempat dimensi tersebut bersifat saling mempengaruhi dan berlangsung dalam satu wadah struktur politik, sosial, ekonomi, dan budaya pada keadaan tertentu (Susanto, 2016).

Hukum Administratif adalah hukum publik yang mengatur hubungan antara negara dan warga negara. Hukum administratif adalah hukum yang mengatur hubungan antara pemerintah dan warga negara, atau hukum yang mengatur hubungan antara lembaga pemerintah. Menurut Philip M. Hadjon, hukum administrasi adalah sarana yudisial dimana pihak berwenang berpartisipasi aktif dalam kegiatan masyarakat, di sisi lain, hukum administrasi adalah hukum yang memungkinkan anggota masyarakat untuk mempengaruhi dan memberikan perlindungan kepada pihak berwenang (Hadjon, 2002).

Dengan bantuan undang-undang dan peraturan yang ada, dapat memberikan dasar dan wewenang bagi pejabat administrasi untuk mengeluarkan keputusan administratif dengan melakukan berbagai fungsi, salah satunya adalah untuk melindungi (mencegah) dan menegakkan hukum dan peraturan, termasuk yang ada di bidang lingkungan. Lisensi administratif adalah otorisasi pemerintah untuk melakukan bisnis dan / atau kegiatan dalam bentuk lisensi, termasuk persyaratan yang harus diperoleh oleh penerima lisensi, seperti izin yang terkait dengan analisis dampak lingkungan, standar kualitas air air limbah, dan pengawasan lainnya. Dan 
sanksi administratif (jika ada) melanggar persyaratan. Menurut Siti Sundari, dalam mencoba untuk memungkinkan bisnis dan / atau kegiatan, kebutuhan untuk penegakan hukum lingkungan dalam administrasi adalah upaya untuk mematuhi peraturan umum dan individu dan ancaman (ancaman) yang dikenakan oleh pengawasan dan aplikasi (Rangkuti \& Wijoyo, 1996).Konsekuensi pemberian lisensi dalam penegakan hukum lingkungan adalah hukum administrasi dalam bentuk hukum administrasi karena melanggar batasan atau ketentuan yang ditetapkan dalam pemberian lisensi. Sanksi adalah alat yang sangat penting dalam penegakan hukum karena jika pemerintah tidak dapat memaksakan aturan ketika melanggar hukum, tidak ada rasa kewajiban atau larangan dalam undang-undang. Sanksi administratif adalah tindakan pencegahan yang diambil oleh pejabat pemerintah. Tujuan sanksi administratif adalah untuk melanggar ketentuan hukum yang berlaku. Sanksi administratif memiliki peran penting dalam mengendalikan perilaku yang dilarang, yaitu pencegahan dan pengendalian perilaku yang bertujuan melindungi kepentingan yang dilindungi oleh pelanggaran peraturan.

Penyelesaian sengketa keperdataan dalam lingkungan hidup dapat ditempuh melalui pengadilan dan di luar pengadilan ini dijelaskan dalam Penjelasan Umum poin 5 alinea kedua Undang-Undang No. 32/2009 yang menyatakan: ".... ketentuan hukum perdata meliputi penyelesaian sengketa lingkungan hidup di luar pengadilan dan di dalam pengadilan. Penyelesaian sengketa lingkungan hidup di dalam pengadilan meliputi gugatan perwakilan kelompok, hak gugat organisasi lingkungan, ataupun hak gugat pemerintah. Melalui cara cara tersebut diharapkan selain akan menimbulkan efek jera juga akan meningkatkan kesadaran seluruh pemangku kepentingan tentang betapa pentingnya perlindungan dan pengelolaan lingkungan hidup demi generasi masa kini dan masa depan".

Melalui penyelesaian perselisihan oleh pengadilan dan penyelesaian perselisihan di luar pengadilan, setiap komunitas memiliki berbagai cara untuk mendapatkan atau menyelesaikan perselisihan atau konflik lingkungan yang mereka hadapi. Dalam pengelolaan lingkungan, sering terjadi perselisihan lingkungan, yang merupakan masalah sipil antara dua pihak atau lebih. Ini terjadi karena ada atau dicurigai pencemaran lingkungan dan / atau kerusakan. Dalam hal ini, perselisihan lingkungan terjadi, sehingga para pihak yang berselisih dapat memilih untuk menyelesaikan perselisihan melalui pengadilan dan di luar pengadilan. Mediasi atau arbitrasi dapat digunakan sebagai cara lain untuk menyelesaikan perselisihan di luar pengadilan.Proses penyelesaian perselisihan lingkungan melalui pengadilan adalah dengan mengajukan gugatan ke pengadilan sesuai dengan Hukum Acara Perdata (Wibisiana, 2019).

Penegakan hukum lingkungan melalui instrumen hukum pidana sebagaimana ditentukan dalam penjelasan umum poin 6 UU No. 32/2009 yang menyatakan: "... penegakan hukum pidana dalam Undang-Undang ini memperkenalkan ancaman hukuman minimum di samping maksimum, perluasan alat bukti, pemidanaan bagi pelanggaran baku mutu, keterpaduan penegakan hukum pidana, dan pengaturan tindak pidana korporasi. Penegakan hukum pidana lingkungan tetap memperhatikan asas ultimum remediumyang mewajibkan penerapan penegakan hukum pidana sebagai upaya terakhir setelah penerapan penegakan hukum administrasi dianggap tidak berhasil. Penerapan asas ultimum remediumini hanya berlaku bagi tindak pidana formil tertentu, yaitu pemidanaan terhadap pelanggaran baku mutu air limbah, emisi, dan gangguan". 
Dalam proses penerapan hukum lingkungan melalui dokumen hukum pidana, prinsip Ultimum Remedium diadopsi. Terlepas dari penerapan prinsip Ultimum Remedium, meskipun terbatas pada tindakan kriminal formal tertentu, yaitu, hukuman atas pelanggaran standar kualitas air limbah, pembuangan dan gangguan, Tidak perlu menerapkan hukum pidana, jika dokumen administrasi dan hukum perdata dianggap tidak berhasil dalam menangani pencemaran dan kerusakan lingkungan, dokumen-dokumen tersebut harus dilakukan kemudian. Keberhasilan atau kegagalan dokumen hukum lainnya hanya dapat digunakan dalam hukum pidana. Oleh karena itu, jika pencemaran dan perusakan lingkungan terjadi, penegakan hukum lingkungan yang dilaksanakan melalui ketiga instrumen hukum ini dapat digunakan secara bersamaan tanpa menunggu instrumen hukum lainnya untuk berhasil atau tidak berhasil mengatasi pencemaran dan perusakan lingkungan. Oleh karena itu, hukum pidana dapat diterapkan tanpa menunggu instrumen hukum lainnya.Oleh karena itu, jika bukti dan unsur-unsur kejahatan lingkungan terpenuhi, instrumen hukum pidana dapat diterapkan. Petugas penegak hukum (polisi dalam kasus ini) dapat secara langsung melakukan penyelidikan dan investigasi untuk menentukan kejahatan lingkungan, dan menemukan bukti serta menghadirkan tersangka tanpa harus menunggu prosedur penegakan hukum yang berhasil melalui cara hukum lainnya.

\section{B. Tanggungjawab Pemulihan Lingkungan dari Negara dan Badan Usaha dalam Kegiatan Investasi Pertambangan yang Berkelanjutan}

Dalam sistem pemerintahan, kekuasaan negara perspektif lingkungan hidup dan sumber daya alam mengandung dimensi kewajiban dan tanggungjawab negara yang sinergi dengan aspek pengendalian yang secara langsung datang dari pihak masyarakat (open control). Dalam aspek pengelolaan lingkungan hidup dan sumber daya alam, negara tidak hanya berperan menguasai dan mendapatkan manfaat yang sebesar-besarnya, meskipun hal itu kemudian peruntukannya ditujukan untuk sebesar-besarnya kemakmuran rakyat (social flourishing). Ketentuan ini sesuai dengan amanat konstitusi sebagaimana diatur dalam ketentuan Pasal 33 ayat (3) Undang-Undang Dasar Negara Republik Indonesia Tahun 1945 (Fadli, Mukhlish, \& Lutfi, 2016). Secara konstitusional, peraturan yang disebutkan di atas terkait dengan pengelolaan lingkungan pada dasarnya adalah tanggung jawab hukum negara untuk semua hal yang berada di bawah kendalinya. Karena bahkan jika kekuasaan negara tersebut terkait dengan semua aspek klausa, makna kekuasaan tidak berarti kepemilikan, tetapi aspek kontrolnya sama dengan kepemilikan. Ketika dijelaskan dalam bahasa lain, kekuatan negara ini akan dianggap menguasai atau menguasai dalam aspek yang lebih realistis. Batas antara keduanya begitu baik sehingga hampir tidak mungkin untuk dibedakan. Karena itu, sesuai dengan slogan hukum, siapa pun yang memilikinya selalu bertanggung jawab.

Kontrol negara atas semua cabang produksi sumber daya alam atau cabang ekonomi yang dianggap vital dan strategis tidak selalu identik dengan kepemilikan. Kekuatan ini berada dalam ruang lingkup pelayanan publik karena sumber daya alam dan lingkungan pada dasarnya adalah komunitas skala besar atau kepentingan publik. Sebagai objek, minat adalah skala kepentingan komunitas dan sifat minat komunitas yang berinteraksi satu sama lain, maka ini tidak diragukan lagi merupakan bagian dari tugas utama negara. Sebagai perwujudan komunitas hukum terbesar, negara adalah penyatuan entitas hukum publik dan memiliki hak untuk memutuskan 
hukumnya sendiri, bahkan jika mereka harus tunduk pada hukum mereka sendiri (Fadli, Mukhlish, \& Lutfi, 2016, p. 54). Menurut Pasal 4 PP 47/2012, dewan direksi harus melakukan tanggung jawab sosial dan lingkungan setelah disetujui oleh dewan direksi atau rapat umum pemegang saham sesuai dengan rencana kerja tahunan dewan dan konstitusi perusahaan. Rencana kerja tahunan perusahaan berisi kegiatan terencana dan anggaran yang diperlukan untuk melaksanakan tanggung jawab sosial dan lingkungan. Pelaksanaan tanggung jawab sosial dan lingkungan dimasukkan dalam laporan tahunan perusahaan dan dijelaskan dalam RUPS Pasal 6 PP 47/2012 Tentang Tanggung Jawab Sosial Dan Lingkungan Perseroan Tebatas (Amalia, 2015).

Menurut Undang-Undang 32 tahun 2009 Pasal 26, Dampak lingkungan hidup adalah pengaruh perubahan pada lingkungan hidup yang diakibatkan oleh suatu usaha dan/atau kegiatan". Izin pengendalian pencemaran lingkungan berdasarkan UUPPLH Dalam hal ini, izin pengendalian pencemaran lingkungan mengacu pada izin lingkungan yang ditetapkan dalam UUPLH Pasal 1 angka 35, tetapi hanya untuk memasukkan mereka yang memberlakukan persyaratan lingkungan pada kegiatan yang dapat menyebabkan pencemaran lingkungan Izin tersebut digunakan untuk kegiatan yang dapat menyebabkan pencemaran lingkungan. Seperti kita ketahui, ketentuan-ketentuan UUPPLH Pasal 123 mensyaratkan bahwa semua izin pengelolaan lingkungan yang dikeluarkan oleh Menteri, Gubernur, Bupati / Walikota di bawah wewenang mereka harus dimasukkan ke dalam izin lingkungan selambat-lambatnya 1 tahun setelah UUPPLH ditetapkan. Ketentuan Pasal 123 UUPPLH mencakup makna retrospektif atau retroaktif, izin yang mengikat kegiatan bisnis harus diintegrasikan oleh pejabat penerbit izin, baik itu menteri, gubernur, atau bupati / walikota. Ketentuan-ketentuan UUPPLH Pasal 123 juga mencakup arti penerapannya di masa depan, yang berarti bahwa sejak UUPPLH diumumkan pada tanggal 3 Oktober 2009, setiap kegiatan bisnis yang harus menjalani penilaian dampak lingkungan atau UKL-UPL hanya tunduk pada satu lingkungan Kendala lisensi. Dasar hukum untuk keberadaan lisensi asuransi jiwa di Indonesia adalah UUPPLH pada tahun 2009, khususnya Pasal 36, Pasal 37, Pasal 38, Pasal 39 dan Pasal 40 dari UUPPLH (Rahma, 2011).

Kementerian Lingkungan Hidup dan Kehutanan dan Kantor Lingkungan bertanggung jawab untuk melindungi dan mengelola kualitas lingkungan untuk mengoptimalkan penggunaan sumber daya alam yang ada. Upaya-upaya praktis telah dibuat dalam beberapa rencana dan kegiatan untuk menyelesaikan masalahmasalah di area bekas penambangan. Pekerjaan Kantor Lingkungan adalah sebagai berikut: Pertama, pengendalian polusi dan rencana perusakan lingkungan. Tujuan dari rencana tersebut adalah untuk meningkatkan kualitas lingkungan untuk mencegah kerusakan, pencemaran lingkungan dan mengembalikan kualitas lingkungan yang telah rusak karena penggunaan sumber daya alam yang berlebihan. Kedua, program perlindungan sumber daya alam dan konservasi. Tujuan dari program ini adalah untuk meningkatkan peran dan perhatian semua pihak yang terlibat dalam pengelolaan sumber daya alam dan pemeliharaan fungsi lingkungan. Beberapa kegiatan yang direncanakan program perlindungan dan konservasi sumber daya alam berkaitan dengan aktivitas pertimbangan (Gate).

Tanggung jawab lingkungan dalam Undang-Undang No. 4 Tahun 2009 dapat diinventarisir sebagai berikut : 
1. Pasal 39 n jo Pasal 78 n, Pemegang IUP/IUPK bertanggung jawab melakukan Amdal. Usaha pertambangan sebagai usaha yang membawa dampak besar dan luas maka perusahaan bertanggung jawab untuk membuat Amdal.

2. Pasal 96 c, d dan e, Pemegang IUP dan IUPK bertanggung jawab untuk menerapkan kaidah teknik pertambangan yang baik, di mana pemegang IUP dan IUPK wajib melaksanakan antara lain pengelolaan dan pemantauan lingkungan pertambangan, termasuk kegiatan reklamasi dan pasca tambang, upaya koservasi sumber daya mineral dan batubara dan pengelolaan sisa tambang dari suatu kegiatan usaha pertambangan dalam bentu padat, cair, atau gas sampai memenuhistandar baku mutu lingkungan sebelum dilepas ke media lingkungan.

3. Pasal 97, pemegang IUP/IUPK bertanggung jawab untuk menjamin penerapan standar baku mutu lingkungan sesuai dengan karakteristik suatu daerah.

4. Pasal 98, pemegang IUP dan IUPK bertanggung jawab menjaga kelestarian fungsi dan daya dukung sumber daya air yang bersangkutan sesuai ketentuan peraturan perundang-undangan.

5. Pasal 99 dan Pasal 100, tentang tanggung jawab pemegang IUP dan IUPK untuk menyerahkan rencana reklamasi dan pasca tambang, melaksanakan dan termasuk menyiapkan jaminan dana reklamasi.

Jika dilihat lebih dalam tanggung jawab pemulihan lingkungan dalam UndangUndang No. 4 Tahun 2009 merupakan penggabungan antara tanggung jawab lingkungan dan tanggung jawab sosial. Argumentasi tersebut didasarkan atas pemahaman bahwa digabungkannya kegiatan reklamasi yang merupakan tanggung jawab lingkungan dengan pasca tambang yang merupakan gabungan antara tanggung jawab sosial dan tanggung jawab lingkungan.

Penjelasan Undang-Undang No. 4 Tahun 2009 secara implisit juga mengisyaratkan bahwa pengelolaan dan pengusahaan sumber daya alam sesuai dengan konsep hukum "kausalitas", di mana keberlajutan perusahaan yang bergerak di bidang pertambangan tergantung pada pemeliharaan sumber daya alam itu sendiri. Sebaliknya, jika daya dukung sumber daya alam rusak, musnah, dan atau tidak ada lagi, maka akan berdampak langsung pada pendapatan masyarakat, sehingga mereka akan menganggap perusahaan sebagai penyebabnya, maka korporasi pemegang IUP atau IUPK diwajibkan dan diatur dalam Undang-Undang tersebut dalam melakukan pemulihan lingkungan (Wordworth, 2008).

Perlindungan dan pengelolaan lingkungan hidup menuntut dikembangkannya suatu sistem yang terpadu berupa suatu kebijakan nasional perlindungan dan pengelolaan lingkungan hidup yang harus dilaksanakan secara taat asas dan konsekuen dari pusat sampai ke daerah.

Apabila dalam pengelolaan lingkungan terjadi perusakan dan pencemaran, maka Pasal 54 UUPPLH menyatakan bahwa setiap orang yang melakukan perusakan dan pencemaran lingkungan wajib melakukan pemulihan fungsi lingkungan dengan antara lain melakukan penghentian sumber perusakan dan pencemaran dan pembersihan unsur pencemar, remediasi, rehabilitasi, restorasi dan cara lain yang sesuai dengan perkembangan ilmu pengetahuan dan teknologi. 
Remediasi adalah upaya pemulihan pencemaran lingkungan hidup untuk memperbaiki mutu lingkungan hidup.Sedangkan pengertian teknis remediasi adalah kegiatan untuk membersihkan permukaan tanah yang tercemar. Ada dua jenis remediasi tanah, yaitu in-situ (atau on-site) dan ex-situ (atau off-site). Pembersihan on-site adalah pembersihan di lokasi. Pembersihan ini lebih murah dan lebih mudah, terdiri dari pembersihan, venting (injeksi), dan bioremediasi. Pembersihan off-site meliputi penggalian tanah yang tercemar dan kemudian dibawa ke daerah yang aman. Setelah itu di daerah aman, tanah tersebut dibersihkan dari zat pencemar. Caranya yaitu, tanah tersebut disimpan di bak/tanki yang kedap, kemudian zat pembersih dipompakan ke bak/tangki tersebut. Selanjutnya zat pencemar dipompakan keluar dari bak yang kemudian diolah dengan instalasi pengolah air limbah. Pembersihan off-site ini jauh lebih mahal dan rumit.

Rehabilitasi adalah upaya pemulihan untuk mengembalikan nilai, fungsi, dan manfaat lingkungan hidup termasuk upaya pencegahan kerusakan lahan, memberikan perlindungan, dan memperbaiki ekosistem. Rehabilitasi lahan ialah usaha memperbaiki, memulihkan kembali dan meningkatkan kondisi lahan yang rusak (kritis), agar dapat berfungsi secara optimal, baik sebagai unsur produksi, media pengatur tata air, maupun sebagai unsur perlindungan alam lingkungan.

Restorasi adalah upaya pemulihan untuk menjadikan lingkungan hidup atau bagian-bagiannya berfungsi kembali sebagaimana semulaekosistem. Restorasi lahan ialah upaya mengembalikan fungsi lahan bekas tambang menjadi seperti keadaan semula.

Selanjutnya ditegaskan oleh Undang-Undang No. 32 Tahun 2009, Pemegang Izin Lingkungan sebagaimana dimaksud dalam Pasal 36 ayat (1) wajib menyediakan dana penjaminan untuk pemulihan fungsi lingkungan hidup. Dana penjaminan disimpan di bank pemerintah yang ditunjuk oleh menteri, gubernur, atau bupati/walikota sesuai dengan kewenangannya. Menteri, gubernur, atau bupati/walikota sesuai dengan kewenangannya dapat menetapkan pihak ketiga untuk melakukan pemulihan fungsi lingkungan hidup dengan menggunakan dana penjaminan.

\section{Peran Serta Masyarakat dalam Mewujudkan Tanggungjawab Pemulihan Lingkungan atas Kegiatan Investasi Pertambangan}

Karakteristik pengelolaan lingkungan untuk tujuan manfaat pembangunan adalah dua isu penting, yaitu ketidakadilan dalam pengelolaan lingkungan. Ketidakadilan dalam pengelolaan lingkungan dan sumber daya alamselama ini, telah menjadi penyebab dari berbagai persoalan lingkungan, seperti perusakan dan pencemaran lingkungan. Konsep pembangunan lingkungan hidup yang hanya menempatkan lingkungan hidup sebagai obyek pembangunan dan kedudukan lingkungan hidup hanya sebagai alat untuk mensejahterahkan manusia sehingga bisa dieksploitasi tanpa batas serta pengelolaan lingkungan yang tidak memperhatikan kebutuhankebutuhan generasi mendatang, telah menjadi isu pokok dalam hubungannya dengan prinsip-prinsip keadilan dalam pengelolaan lingkungan hidup.

Penerapan prinsip keadilan dalam pengelolaan lingkungan dan sumber daya alam menjadi penting terkait dengan pelaksanaan hak menguasai negara pada satu sisi, 
diperhadapkan dan hak-hak masyarakat atas lingkungan hidup yang sehat dan baik di sisi lain.

Di satu sisi, lingkungan dan sumber daya alam hanya digunakan sebagai objek pembangunan untuk memenuhi kepentingan dan kebutuhan manusia, dan di sisi lain dikendalikan oleh negara. Prinsip-prinsip hak dalam manajemen lingkungan dan kebijakan manajemen. Di sisi lain, ada sumber daya alam utama, yaitu, pelanggaran hak-hak orang untuk menentukan hak mereka terhadap lingkungan dan sumber daya alam yang mereka kendalikan (Silalahi, 2003).

Sejauh ini, ketidakadilan dalam pengelolaan lingkungan dan sumber daya alam telah menjadi penyebab berbagai masalah lingkungan, seperti kerusakan lingkungan dan polusi. Konsep pembangunan lingkungan telah menjadi isu penting terkait prinsip keadilan dalam pengelolaan lingkungan.Konsep pembangunan lingkungan hanya menganggap lingkungan sebagai objek pembangunan, dan status lingkungan hanya digunakan sebagai alat untuk kesejahteraan manusia, sehingga dapat digunakan tanpa batasan dan Kelola lingkungan tanpa memperhatikan kebutuhan generasi mendatang.

Penerapan prinsip keadilan dalam pengelolaan lingkungan dan sumber daya alam menjadi penting terkait dengan pelaksanaan hak menguasai negara pada satu sisi, diperhadapkan dan hak-hak masyarakat atas lingkungan hidup yang sehat dan baik di sisi lain.

Pasal 28 H UUD NRI 1945 sebagai jaminan hak atas lingkungan hidup yang sehat dan baik merupakan hak yang dimiliki setiap makhluk hidup, terutama manusia, sehingga setiap orang harus diberikan akses kekuasaan dalam pengambilan keputusan terhadap pengelolaan lingkungan hidup dan sumber daya alam, termasuk dalam kegiatan investasi pertambangan. Dengan demikian pengakuan hak atas lingkungan yang baik dan sehat sebagai hak asasi setiap warga Negara di Indonesia dan kanstitusional bagi setiap warga Negara. Maka Negara, pemerintah, dan seluruh pemangku kepentingan berkewajiban untuk melakukan perlindungan dan pengelolaan lingkungan hidup dalam pelaksanaan pembangunan berkelanjutan.

Partisipasi masyarakat dalam menentukan langkah-langkah yang harus diambil dalam pengelolaan lingkungan dan sumber daya alam adalah implementasi atau penerapan nilai-nilai keadilan masyarakat yang menentukan atau menentukan pengelolaan lingkungan dan sumber daya alam (termasuk tanggung jawab untuk melindungi, mengelola dan memulihkan lingkungan). , Jika kawasan itu memiliki pengelolaan sumber daya alam, terutama pengelolaan pertambangan.Ketika paradigma pembangunan, khususnya pendekatan tata pemerintahan yang baik, dianggap melibatkan tiga pilar utama pembangunan, yaitu pemerintah, sektor swasta, dan konsep kesetaraan demokratis masyarakat, partisipasi masyarakat menjadi penting (Kompasiana, 2010).

Hukum lingkungan, termasuk hukum pengelolaan sumber daya alam, telah bergeser dari sifat awalnya yang tidak demokratis kearah hukum yang demokratis yang ditandai dengan berkembangnya prinsip-prinsip good governance dalam pengelolaan lingkungan hidup dan diakomodirnya peran serta masyarakat dalam produk-produk hukum lingkungan dan pengelolaan sumber daya alam. 
Untuk melihat apakah suatu perangkat hukum atau perundangundangan dibidang sumber daya alam mendukung perwujudan pemerintahan yang baik dan memberikan pengakuan aspek perlindungan daya dukung lingkungan/ekosistem (good environmental governance), maka perlu ditentukan paling tidak 8 (delapan) kriteria sebagai berikut (Indonesia Center for Environmental Law (ICEL), 1999):

1. Pemberdayaan masyarakat. Kriteria ini dimaksudkan untuk melihat apakah peraturan perundang-undangan mengakui aspek pemberdayaan masyarakat (people's empowerment) melalui berbagai peluang agar masyarakat dapat terlibat dalam proses pengambilan keputusan, tersedianya akses publik terhadap informasi agar publik dapat berpartisipasi secara efektif, dan hak masyarakat (khususnya masyarakat yang selama ini menggantungkan hidupnya pada sumber daya alam dan ekosistemnya) untuk mendapatkan prioritas menikmati dan mendapatkan manfaat dari sumber daya alam tersebut.

2. Transparansi. Kriteria ini erat terkait dengan kriteria pertama dan dapat dijadikan tolok ukur apakah suatu peraturan perundang-undangan menjamin keterbukaan dalam konteks pengelolaan sumber daya alam dimaksud.

3. Desentralisasi yang demokratis. Tolak ukur untuk menguji apakah desentralisasi yang demokratis, termasuk pemberdayaan masyarakat local dan Dewan Perwakilan Rakyat Daerah diakui serta difasilitasi dalam peraturan perundangundangan yang terkait dengan pengelolaan sumber daya alam dan lingkungan hidup.

4. Pengakuan terhadap daya dukung ekosistem dan keberlanjutan. Pengakuan ini sangat penting dilakukan terutama dalam peraturan perundang-undangan tentang sumber daya alam tertentu yang rentan terhadap pengurasan, kerusakan dan kepunahan (kehutanan, pertambangan, minyak dan gas, kelautan, sumber daya air). Pengakuan ini tidak terbatas pada pengakuan tekstual (misalnya pernyataan simbolik dalam suatu mukadimah), akan tetapi secara konsisten pengakuan tersebut mengalir kedalam tubuh peraturan perundangundangan yang memperjelas langkah-langkah untuk mencegah serta menanggulangi pengurasan dan perusakan sumber daya alam, serta pencemaran melalui piranti managemen lingkungan, instrumen ekonomi, instrumen daya paksa (enforcement atau command \& control), moral suassion maupun control public.

5. Pengakuan hak masyarakat lokal dan masyarakat setempat. Pengakuan secara tegas tentang hal ini dalam suatu produk hukum sangatlah penting karena pada umumnya masyarakat lokal dan masyarakat setempat bergantung hidupnya pada sumber daya alam disekelilingnya, dan masyarakat lokal merupakan penjaga daya dukung ekosistem dan lingkungan mereka. Pengakuan terhadap hak-hak mereka juga diperlukan untuk mencegah terjadinya pelanggaran atas hak-hak mereka dari arus pembangunan dan penanaman modal yang berlangsung dengan sangat cepat.

6. Konsistensi dan harmonisasi. Konsistensi adalah kesesuaian substansi antara pasal dengan pasal-pasal lainnya dalam suatu produk hukum. Sedangkan harmonisasi adalah kesesuaian antara substansi dalam satu peraturan perundang-undangan dengan substansi yang terdapat dalam semangat yang tercermoin dalam konstitusi, peraturan perundang-undangan maupun konvensi-konvensi internasional yang diakui oleh banyak negara-negara di dunia, terlepas apakah kita meratifikasi konvensi tersebut atau tidak. 
7. Kejelasn (clarity). Kejelasan suatu peraturan perundang-undangan sangatlah penting untuk menjamin adanya kepastian hukum. Di samping itu kejelasan akan mempengaruhi daya penegakan (enforceability).

8. Enforceability. Daya penegakan (enforceability) ditentukan oleh (a) ketersediaan sanksi yang mampu menimbulkan efek jera (deterrent effect); (b) ketersediaan 3 (tiga) jenis sarana sanksi yang terdiri dari sanksi administrative, pidana dan perdata; (c) ketersediaan mekanisme pengaduan masyarakat dan penindaklanjutannya terhadap pelanggaranpelanggaran hak yang dialami masyarakat; (d) ketersediaan mekanisme pengawasan penataan terhadap persyaratan lingkungan; (e) ketersediaan institusi dan aparat khusus yang melakukan pengawasan penataan, penyelidikan, penyidikan, penuntutan, bahkan pengadilan.

Kedelapan kriteria ini merupakan parameter yang mendorong terciptanya pemerintahan yang baik, terutama melalui penguatan masyarakat sipil. Pemberdayaan masyarakat dan dan transparansi serta desentralisasi yang bersifat demokratik merupakan elemen pokok untuk mewujudkan pemerintah yang baik. Sedangkan pengakuan terhadap keterbatasan daya dukung ekosistem dan aspek keberlanjutan, serta pengakuan hak masyarakat lokal dan masyarakat setempat merupakan elemenelemen pokok dari prinsip keberlanjutan ekologis (ecologically sustainable). Adapun konsistensi dan harmonisasi, serta kejelasan (clarity) dan daya penegakan (enforceability) merupakan elemen-elemen penting dari rule of law.

Jika dilihat kebelakang, masalah-masalah pertambangan di Indonesia ditandai dengan terjadinya konflik antara masyarakat lokal/masyarakat adat dengan pemerintah dan perusahaan pada pihak lain. Konflik tersebut muncul sebagai akibat adanya dualisme pemahaman terhadap hak-hak masyarakat dengan hak-hak milik negara yang dilaksanakan oleh pemerintah dan perusahaan pertambangan.

Masyarakat lokal dan masyarakat adat seringkali merasa tidak didengar maupun diperhitungkan, baik dalam hukum nasional maupun dalam pelaksanaan hukum/hak tersebut di daerah-daerah yang menjadi tempat/lokasi pertambangan.

\section{KESIMPULAN}

Tanggung jawab Negara sebagai dasar pelaksanaan perlindungan dan pengelolaan lingkungan hidup dilaksanakan melalui penegakan hukum lingkungan, yaitu penegakan hukum administrasi, perdata dan pidana. Di antara ketiga bentuk penegakan hukum yang tersedia, penegakan hukum administrasi dianggap sebagai upaya penegakan hukum terpenting. Hal ini karena penegakan hukum administrasi lebih ditujukan kepada upaya mencegah terjadinya pencemaran dan perusakan lingkungan. Di samping itu, penegakan hukum administrasi juga bertujuan untuk menghukum pelaku pencemaran dan perusakan lingkungan. Kedua implikasi pemulihan lingkungan usaha investasi pertambangan pada kelestarian fungsi sumberdaya alam dan lingkungan yang berkelanjutan lebih menitikberatkan pada pemulihan lingkungan fisik yaitu dengan menegaskan pentingya izin lingkungan dalam usaha pertambangan. Namun, kewajiban pemulihan lingkungan sosial dan ekonomi sebagai dampak suatu usaha investasi pertambangan masih berada pada wilayah yang tidak tegas karena dalam UU No. 4 Tahun 2009 hal tersebut hanya 
diletakkan pada kewajiban sosial perusahaan bukan merupakan kewajiban dari Negara.

\section{SARAN}

Pada tanggungjawab pemulihan lingkungan perlu diberikan ketegasan terhadap tanggungjawab Negara, perusahaan, dan masyarakat sekitar pada akibat-akibat pencemaran yang terjadisetelah terjadinya penyerahan reklamasi dan/atau pascatambang serta tanggungjawab pemulihan lingkungan sosial dan ekonomi oleh badan usaha yang harus diatur secara khusus dalam perundang-undangan yang berlaku.

\section{UCAPAN TERIMA KASIH}

Penulis menyampaikan terimakasih yang tak terhingga kepada orang tua yang selama ini membimbing dan mendidik penulis. Terimakasih kepada Rektor Universitas Indonesia. terimakasih kepada Ketua Pascasarjana Universitas Indonesia. terimakasih kepada komisi pembimbing yang telah meluangkan waktunya dan memberikan ilmu kepada penulis. Terimakasih kepada komisi penguji yang telah meluangkan waktunya untuk memberikan masukan kepada penulis. Terimakasih kepada seluruh dosen program Magister ilmu Hukum pada pascasarjana Universitas Indonesia dan terimakasih kepada seluruh karyawan pascasarjana Universitas Indonesia serta terimakasih kepada seluruh rekan-rekan penulis yang sama-sama kuliah di pascasarjana Universitas Indonesia. 


\section{DAFTAR PUSTAKA}

\section{Buku :}

Ambadar, J. (2008). CSR dalam Praktik di Indonesia. Jakarta (ID): PT Elex Media Komputindo.

Boedeltje, M., \& Cornips, J. (2004). Input and output legitimacy in interactive governance (No. NIG2-01).

Butar, F. B. (2010). Penegakan Hukum Lingkungan di Bidang Pertambangan. Yuridika, 25(2), 151-168.

Fadli, M., \& Lutfi, M. (2016). Hukum dan Kebijakan Lingkungan. Universitas Brawijaya Press.

Hadjon, P. M. (2002). Pengantar Hukum Administrasi Indonesia (Introduction to the Indonesian Administrative Law).

Rangkuti, S. S., \& Wijoyo, S. (1996). Penegakan Hukum Lingkungan Administrasi. Makalah, Penataran Nasional Hukum Lingkungan (eks) Kerjasama Hukum (Surabaya: Fakultas Hukum Universitas Airlangga) Indonesia-Belanda.

Rahmadi, T. (2011). Hukum Lingkungan di Indonesia, PT. Raja Grafindo Persada, Jakarta.

Saleng, A. (2004). Hukum pertambangan. UII press.

Sidharta, B. A., \& Brugguink, J. J. H. (1999). Refleksi tentang hukum. Citra Aditya.

Soemarwoto, O. (2001). Atur-diri-sendiri: paradigma baru pengelolaan lingkungan hidup: pembangunan ramah lingkungan: berpihak pada rakyat, ekonomis, berkelanjutan. Gadjah Mada University Press.

Supriadi, H. L. D. I. (2008). sebuah Pengantar. Sinar Grafika, Jakarta.

\section{Jurnal dan Makalah :}

Amalia, E. (2019). REGULASI TANGGUNG JAWAB SOSIAL PERUSAHAAN DI INDONESIA. ADIL: Jurnal Hukum, 10(2).

Herlan, H. (2017). Pertanggungjawaban Korporasi Terhadap Kerusakan Lingkungan Di Kabupaten Morowali. Maleo Law Journal, 1(1), 119-134.

Mukhlish, M. (2016). Konsep Hukum Administrasi Lingkungan Dalam Mewujudkan Pembangunan Berkelanjutan. Jurnal Konstitusi, 7(2), 067-098.

Silalahi, D., VIII, S. P. H. N., \& NASIONAL, B. P. H. (2003, July). Pembangunan Berkelanjutan dalam rangka Pengelolaan (termasuk perlindungan) sumber daya alam yang berbasis Pembangunan Sosial dan Ekonomi. In Makalah disampaikan pada Seminar Pembangunan Hukum Nasional VIII, Tema Penegakan Hukum dalam Era Pembangunan Berkelanjutan diselenggarakan oleh Badan Pembina Hukum Nasional Departemen Kehakiman dan Hak Asasi Manusia RI Denpasar(pp. 14-18).

Suprijadi, D. A. P. (2019). KAJIAN HUKUM PEMULIHAN PENCEMARAN LINGKUNGAN DAERAH BEKAS PERTAMBANGAN MENURUT $\begin{array}{lllll}\text { UNDANG-UNDANG NOMOR } & 32 & \text { TAHUN } & 2009 & \text { TENTANG }\end{array}$ 
PERLINDUNGAN DAN PENGELOLAAN LINGKUNGAN HIDUP. LEX ET SOCIETATIS, 7(3).

Wibisana, A. G. (2019). Instrumen Ekonomi, Command and Control, Dan Instrumen Lainnya: Kawan Atau Lawan? Suatu Tinjauan Berdasarkan Smart Regulation. Bina Hukum Lingkungan, 4(1), 172-197.

\section{Peraturan Perundang-Undang :}

Indoneria, R. (1945). Undang-Undang Dasara Negara Republik Indonesia.

Indonesia, R. (2009). Undang-Undang Nomor 4 Tahun 2009 Tentang Pertambangan Mineral Dan Batu Bara, LN 4 Tahun 2009, TLN Nomor 4959

Indonesia, R. (2012). Peraturan Pemerintah Nomor 47 Tahun 2012 Tentang Tanggung Jawab Sosial Dan Lingkungan Perseroan Tebatas

\section{Website :}

www.researchgate.net/upaya_dinas_lingkungan_hidup/ Diunduh pada Tanggal 29 Mei 2020

http://hukum.kompasiana.com/perlindungan-dan-pengelolaanlingkunganhidup dalam-usaha pertambangan, diunduh pada_28 Mei 2020

https:/www.suara.com/bisnis/2020/03/23/162330/daftar-saham-perusahaan-tambang-yangambruk-karena-virus-corona Diunduh pada tanggal 19 Oktober 2020 